\title{
PENYELESAIAN PERSELISIHAN KARYAWAN MELALUI MEDIASI (STUDI KASUS DI TOKO HOUSE OF CELENA )
}

\author{
Ahmad Ashari, Novalinda Fajar Astari, Uswatun Hasanah \\ Universitas Trunojoyo Madura
}

\begin{abstract}
Mediation is the process of resolving the parties who are assisted by a neutral third party who does not take sides as a facilitator where the decision is taken based on the agreement of the parties to the dispute. This study aims to find out how to mediate between employees because of a conflict at the House Of Celena Store. In the House Of Celena Store there are conflicts including conflicts between employees and employees and different opinions between employees and managers. This research is the result of interviews about conflicts that occur between employees and employees and different opinions between employees and managers. As well as the factors that influence the harmony of industrial relations between superiors or owners of the House Of Celena ShopThe results of this study indicate that the strategies that managers do to mediate between hostile employees and the opinions between different managers and employees.
\end{abstract}

Keywords: mediation, dispute resolution

\section{PENDAHULUAN}

Hubungan Industrial menurut Undang-Undang Nomor 13 Tahun 2003 tentang Ketenagakerjaan Pasal 1 angka 16 yaitu : "Suatu system hubungan yang terbentuk antara para pelaku dalam proses produksi barang atau jasa yang terdiri dari unsur pengusaha, pekerja atau buruh, dan pemerintah yang didasarkan pada nilai Pancasila dan UndangUndang Dasar Negara Republik Indonesia Tahun 1945”. Jadi dapat disimpulkan hubungan industrial merupakan hubungan antara semua pihak yang terkait atau berkepentingan atas proses produksi atau pelayanan jasa disuatu perusahaan. Hubungan tersebut harus diciptakan dengan sekuat tenaga agar aman, harmonis, serasi dan sejalan agar perusahaan dapat terus meningkatkan produktivitasnya untuk meningkatkan kesejahteraan para pihak yang terkait. Namun, tidak dapat dipungkiri perselisihan antar pihak yang terkait dalam suatu perselisihan masih sangat sering terjadi sehingga banyak timbul permasalahan mengenai perselisihan hubungan industrial.

Pengertian dari perselisihan hubungan industrial telah tercantum secara jelas dalam Pasal 1 angka 1 Undang-Undang Nomor 2 Tahun 2004 tentang Penyelesaian Perselisihan Hubungan Industrial : "Perselisihan Hubungan Industrial adalah perbedaan pendapat yang 
mengakibatkan pertentangan antara pengusaha atau gabungan pengusaha dengan pekerja atau buruh atau serikat pekerja atau serikat buruh karena adanya perselisihan mengenai hak, perselisihan kepentingan, perselisihan pemutusan hubungan kerja dan perselisihan antar serikat pekerja atau serikat buruh dalam satu perusahaan.

Berdasarkan Pasal 1 angka 1 Undang-Undang Nomor 2 Tahun 2004 tentang Penyelesaian Perselisihan Hubungan Industrial tersebut diatas maka terdapat empat macam atau jenis perselisihan hubungan industrial yaitu :

1. Perselisihan mengenai hak,

2. kepentingan,

3. pemutusan hubungan kerja,

4. Perselisihan antar serikat pekerja atau serikat buruh dalam satu perusahaan.

Realita yang terjadi saat ini menggambarkan bahwa tidak selalu hubungan industrial berjalan dengan baik dan lancar. Setiap hubungan industrial akan terjadi perbedaan pendapat maupun kepentingan antara pengusaha dan pekerja atau buruh yang dapat menimbulkan suatu perselisihan atau konflik. Pengusaha memberikan kebijakan yang menurutnya benar tetapi pihak pekerja atau buruh menganggap bahwa kebijakan yang telah ditetapkan oleh pengusaha tersebut merugikan mereka. Hal ini yang terkadang sering menjadi awal dari terjadinya perselisihan hubungan industrial.

Mediasi merupakan suatu proses penyelesaian sengketa antara dua pihak atau lebih melalui perundingan atau cara mufakat dengan bantuan pihak netral yang tidak memiliki kewenangan memutus. Pihak netral tersesebut disebut mediator dengan tugasnya memberikan bantuan procedural dan substansial. Sehingga unsur-unsur esensial mediasi yaitu :

1. Mediasi merupakan suatu cara penyelesaian sengketa melalui perundingan berdasarkan pendekatan mufakat atau consensus para pihak.

2. Para pihak meminta bantuan kepada pihak lain yang bersifat tidak memihak yang disebut mediator.

3. Mediator tidak memiliki kewenangan memutus perselisihan tetapi hanya membantu para pihak yang bersengketa dalam mencari penyelesaian yang dapat diterima para pihak. Mediasi berfungsi sebagai salah satu bentuk atau cara penyelesaian perselisihan dapat ditemukan dalam beberapa peraturan perundang- 
undangan dalam berbagai bentuk konsteks perselisihan. Salah satunya mediasi untuk penyelesaian perselisihan .

Perselisihan hubungan industrial yang telah terjadi sebenarnya dapat diselesaikan oleh para pihak yang berselisih melalui perundingan bipatrit yaitu musyawarah antara pekerja dengan pengusaha. Namun, karena salah satu pihak tidak ada yang bersedia mengalah sehingga cara penyelesaian tersebut tidak mampu menyelesaikan perselisihan yang terjadi. Terdapat beberapa lembaga penyelesaian perselisihan hubungan industrial jika tidak terdapat kesepatan antar pihak secara bipartite yaitu melalui mediasi, konsiliasi, arbitrase dan lembaga pengadilan hubungan industrial.

Keputusan seseorang karyawan untuk bertahan tetap bekerja dalam suatu perusahaan memang sangat tergantung dari berbagai hal, terutama akibat adanya berbagai perubahan. idak sedikit yang bekerja seumur hidupnya hanya disalah satu perusahaan, artinya tidak pernah pindah ke perusahaan lain, karena memang perusahaan mampu memberikan seperti yang diinginkannya. Namun banyak pula yang berpindah-pindah dari satu perusahaan ke perusahaan lainnya, berkali-kali, karena selalu merasa tidak puas apa yang telah diterimanya. Dalam praktiknya karyawan yang dimiliki oleh suatu perusahaan tentu memiliki karakter atau perilaku yang berbeda satu sama lainnya. Artinya karyawan dapat saja bertindak di luar seperti yang diinginkan perusahaan dengan berbagai sebab, misalnya berbuat kecurangan yang dapat merugikan hal ini tentu akan merepotkan pihak manajemen dan diberikan tindakan tegas, misalnya salah satunya adalah dikeluarkan dari perusahaan agar tidak merugikan perusahaan lebih besar lagi. Atau ¡ika kesalahannya masih dapat dimaafkan maka diberikan sanksi peringatan atau penggantian akibat kerugian yang diderita. Penyelesaian perselesihan hubungan industrial yang berwenang menyelesaiakan semua jenis perselisihan hubungan industrial merupakan dengan cara mediasi. Penyelesaian perselisihan dengan mediasi mengandung unsur-unsur sebagai berikut pertama, merupakan proses penyelesaian perselisihan berdasarkan perundingan, kedua, pihak ketiga netral yang bisa disebut sebagai mediator terlibat dan diterima oleh para pihak yang bersangkutan di dalam perundingan, ketiga, mediator bertugas membantu para pihak yang berselisih untuk mencari jalan keluar penyelesaian atas masalah-masalah, keempat, mediator tidak memiliki kewenangan membuat keputusan selama proses perundingan berlangsung, dan kelima, tujuan mediasi adalah untuk mencapai atau 
menghasilkan kesepakatan yang dapat diterima oleh pihak-pihak yang berselisih guna mengakhiri perselisihan.

Mediator yang netral memiliki pengertian bahwa mediator tidak berpihak (impartial), tidak memiliki kepentingan dengan perselisihan yang sedang terjadi, serta tidak diuntungkan atau dirugikan jika sengketa dapat diselesaikan atau jika mediasi menemui jalan buntu (deadlock).Hal demikian penting agar hasil dari mediasi tersebut dapat membawa keadilan terhadap para pihak yang berselisih. Berdasarkan ketentuan yang berlaku umum, penyelesaian sengketa melalui mediasi tidak terdapat memiliki unsur paksaan antar para pihak dan mediator, para pihak meminta secara sukarela kepada mediator untuk membantu penyelesaian konflik yang terjadi. Oleh karena itu, mediator hanya berkedudukan membantu para pihak agar dapat mencapai kesepakatan yang hanya bisa dapat diputuskan oleh para pihak yang berselisih.

Sebagai pihak yang berada di luar pihak yang berselisih, mediator tidak memiliki kewenangan untuk memaksa, mediator berkewajiban untuk bertemu atau mempertemukan para pihak yang berselisih. Setelah mengetahui suatu perkara, mediator dapat menyimpulkan sebuah perkara di Toko House Of celena tersebut . Mediator harus mampu menciptakan kondisi yang kondusif dan harmonis yang dapat menjamin terciptanya kompromi di antara pihak-pihak yang bersengketa untuk memperoleh hasil yang samasama menguntungkan (win-win). Jika proposal penyelesaian yang ditawarkan oleh mediator disetujui, mediator menyusun kesepakatan itu secara tertulis untuk ditandatangani olehkedua pihak.Untuk menghindari adanya suatu perselisihan dalam hubungan industrial diperlukan peran beberapa pihak-pihak yang terkait.

\section{TINJAUAN PUSTAKA}

\section{Pengertian hubungan industrial menurut para ahli :}

Menurut Simanjuntak (2011) Hubungan industrial adalah Hubungan semua pihak yang terkait atau berkepentingan atas proses produksi barang atau jasa di suatu perusahaan. Filosofi dan kebijakan sebuah organisasi yang berkaitan dengan pekerja. Para manajer dan departemen SDM secara langsung mempengaruh hubungan pekerja melalui aktivitas komunikasi di penyuluhkan, dan penerapan disiplin. 
Menurut SHRM Knowledge Center, Employee relations adalah sebuah terminologi umum yang digunakan untuk merujuk kepada the general management and planning of activities related to developing, maintaining and improving employee relationships by communicating with employees, processing grievances/disputes, etc." (manajemen dan perencanaan kegiatan-kegiatan yang terkait dengan pengembangan, pemeliharaan dan peningkatan hubungan dengan pekerja dengan cara di komunikasi dengan pekerja, memroses keluh kesah/perselisihan, dan sebagainya).

Menurut Armstrong, istilah employee relations hubungan industrial (industrial relations), yang mencakup juga hubungan antara manajemen dengan serikat pekerja kesepakatan bersama (collective agreements), perundingan (collective bargaining), penyelesaian perselisihan dan lingkungan kerja. Bogardus menggunakan istilah employee and labor relations dan mendefinisikannya sebagai "the functional area of the HR body of ununion environments" (bidang fungsional dari ilmu manajemen sumber daya manusia yang membahas hubungan kerja dalam organisasi yang memiliki serikat pekerja maupun yang tidak).

Heidjrahman berpendapat bahwa hubungan industrial secara garis besar dibedakan menjadi dua, yaitu masalah man power marketing dan masalah manpower management.

Dari kedua kategori ini dapat dirinci lagi menjadi bagian-bagian masalah yang lebih detail. Secara garis besar ruang lingkup hubungan industrial dibedakan menjadi dua, yaitu: man power marketing dan man power management. Kemudian dari kedua garis besar pembagian ini dapat diuraikan lagi sebagai berikut.

1. Man Power Marketing

Man Power Marketing atau pemasaran tenaga kerja secara umum membahas penentuan syarat-syarat kerja yang akan diterapkan dalam pelaksanaan ikatan kerja yang ada. Proses ini terjadi setelah karyawan dinyatakan diterima oleh pihak perusahaan. Penentuan syarat-syarat kerja ini dapat dilaksanakan oleh pekerja secara individual yang selanjutnya disebut individual bargaining maupun oleh wakil-wakil pekerja yang tergabung, yang disebut dengan collective bargaining. Syarat-syarat kerja yang akan ditentukan dalam proses tersebut biasanya meliputi jam kerja, hari kerja, tempat kerja, upah dan jaminan sosial

2. Man Power Management 
Man Power Management membahas pelaksanaan syarat-syarat kerja dan berbagai permasalahan serta pemecahannya. Oleh karena itu, proses ini terjadi setelah karyawan bergabung dengan perusahaan. Pelaksanaan syarat-syarat kerja dengan berbagai permasalahan dan pemecahannya dapat diterapkan kepada pekerja secara individual maupun kepada keseluruhan karyawan melalui organisasi pekerja. Dalam praktiknya pelaksanaan syarat-syarat kerja ini berlaku umum, namun dalam penanganan pelaksanaan syarat kerja beserta permasalahan dan pemecahannya diterapkan secara individu. Dalam kasus seperti ini berarti menyangkut personal management. Penanganan permasalahan dan pemecahannya juga dapat dilakukan secara kelompok, melalui organisasi buruh. Dalam hal seperti ini, maka kelompok pekerja tersebut akan mewakilkan pelaksanaan syarat-syarat kerja, penanganan permasalahan dan pemecahannya ke organisasi pekerja, yang selanjutnya disebut labour relation. Sebagai konsekuensinya, para pekerja tersebut harus menerima pelaksanaan syarat-syarat kerja, dan pemecahan permasalahannya kepada serikat pekerja. Secara terperinci pelaksanaan syarat-syarat kerja, permasalahan yang dihadapi dan pemecahannya yang diwakilkan kepada serikat pekerja akan meliputi: penarikan tenaga kerja, pengembangan tenaga kerja, kompensasi, integrasi, pemeliharaan.

\section{Pengertian Mediasi}

J. Folberg dan A. Taylor, Mediasi adalah proses dimana para peserta, bersamasama dengan bantuan dari orang yang netral, sistematis mengisolasisengketa dalam rangka untuk mengembangkan pilihan, mempertimbangkan alternatif dan mencapai penyelesaian sengketa yang akan mengakomodasi kebutuhan mereka.

Garry Goopaster mengemukakan pengertian mediasi, Mediasi ialah suatu proses negosiasi pemecahan masalah di mana pihak luar yang tidak memihak (imparsial) bekerja sama dengan pihak-pihak yang bersengketa untuk membantu mereka memperoleh kesepakatan perjanjian yang memuaskan.

Pengertian Mediasi menurut Christopher W. Moore, Mediasi adalah intervensi dalam negosiasi atau konflik dari pihak ketiga yang dapat diterima yang terbatas atau tidak ada keputusan otoritatif membuat kekuasaan, tetapi membantu pihak-pihak yang terlibat dalam sukarela mencapai penyelesaian yang saling diterima dalam sengketa. 
Pengertian Mediasi yang diungkapkan oleh Laurence Belle di atas menekankan bahwa mediasi adalah proses pengambilan keputusan yang dilakukan para pihak yang dibantu oleh pihak ketiga sebagai mediator. Pernyataan Belle menunjukkan bahwa kewenangan pengambilan keputusan sepenuhnya berada di tangan para pihak dan mediator hanyalah membantu para pihak di dalam proses pengambilan keputusan nantinya. Kehadiran mediator merupakan faktor yang sangat penting karena mediator dapat membantu dan mengupayakan proses pengambilan keputusan menjadi lebih baik, sehingga menghasilkan keputusan akhir yang dapat diterima oleh mereka yang bertikai.

\section{Pemutusan Hubungan Kerja}

Menurut Undang-Undang Nomor 13 Tahun 2003 tentang Ketenagakerjaan, pengertian pemutusan hubungan kerja adalah pengakhiran hubungan kerja karena suatu hal tertentu yang mengakibatkan berakhirnya hak dan kewajiban antara pekerja/buruh dan pengusaha. Dari kedua definisi di atas dapat disimpulkan bahwa pemutusan hubungan kerja berisi:

1. Berakhirnya hubungan perjanjian kerja antara karyawan dengan pihak perusahaan, artinya karyawan sudah tidak bekerja lagi setelah keluarnya surat pemutusan kerja dan perusahaan tidak mempekerjakan lagi sebagai karyawan. Dan kalau pun tenaganya masih dibutuhkan, maka dapat dikaryakan, namun tetap dipensiunkan lebih dulu. Pada saat dikaryakan karyawan tersebut digaji dengan kontrak tertentu.

2. Dikeluarkannya surat keputusan pemberhentian dengan menyebutkan alasan pemberhentian, baik yang sudah memasuki usia pensiun atau bagi yang mengundurkan diri atau yang dikeluarkan.

3. Perusahaan membayar hak-hak karyawan sesuai dengan peraturan perundangundangan yang berlaku, seperti misalnya uang pensiun (baik sekaligus atau bulanan), uang jasa, uang penghargaan atau uang lainnya.

4. Karyawan diwajibkan membayar kewajiban atas perbuatannya jika ada, khusus untuk karyawan yang diberhentikan dengan alasan tertentu. terutama yang merugikan perusahaan, misalnya mengganti akibat perbuatannya. Khusus bagi mereka yang pendidikanya dibiayai perusahaan dan masih dalam ikatan dinas, maka diwajibkan mengganti biaya pendidikan sesuai dengan perjanjian yang sudah dibuat sebelumnya. 


\section{Konflik Kerja}

Konflik Kerja adalah segala macam interaksi pertentangan atau antagonistik antara dua atau lebih pihak. Konflik organisasi (Organizational Conflict) adalah ketidaksesuaian antara dua atau lebih anggota - anggota atau kelompok - kelompok organisasi yang timbul karena adanya kenyataan bahwa mereka harus membagi sumber daya - sumber daya yang terbatas dan atau kegiatan - kegiatan kerja dan atau karena kenyataan mereka mempunyai perbedaan status, tujuan, nilai, atau prespsi. Konflik adalah suatu pertentangan yang terjadi antara apa yang diharapkan oleh seseorang terhadap dirinya, orang lain, organisasi dengan kenyataan apa yang diharapkan. Kinerja Karyawan Kinerja merupakan salah satu bentuk hasil dari pekerjaan seorang karyawan ataupun pekerja dalam suatu perusahaan. Menurut Wahyudi (2006:68) menyatakan bahwa kinerja atau performasi kerja adalah hasil kerja sebagai gambaran pekerjaan yang telah dilakukan didalam organisasi. Menurut Wirawan (2009:5) kinerja adalah keluaran yang dihasilkan oleh indikator - indikator suatu pekerjaan atau suatu profesi dalam waktu tertentu. Menurut Florent (2010) kinerja merupakan prestasi kerja seseorang dalam melaksanakan tugas dan pekerjaan yang diberikan kepadanya didalam suatu perusahaan yang meliputi kejujuran, loyalitas, kedisiplinan, kerjasama, tanggung jawab, sikap, kehadiran, kuantitas, pekerjaan, kualitas kerja, dan peningkatan kerja. Performance atau kinerja adalah hasil kerja yang dapat dicapai oleh seseorang atau sekelompok orang dalam suatu organisasi, sesuai dengan wewenang dan tanggungjawab masing - masing, dalam rangka upaya mencapai tujuan organisasi bersangkutan secara legal, tidak melanggar hukum dan sesuai dengan moral maupun etika (Sedarmayanti, 2007:260).

Hubungan Konflik Kerja Terhadap Kinerja Karyawan Hubungan antar individu dalam lingkungan kerja dan dampak positif atau negatif yang ditimbulkan merupaka sumber motivasi dan kepuasan kerja yang sangat mempengaruhi kinerja organisasi, oleh karena itu sangat penting untuk menciptakan suatu kondisi lingkungan kerja yang kondusif. konflik dalam organisasi disebut sebagai The conflict Paradoks, yaitu pandangan bahwa di sisi konflik dianggap dapat meningkatkan kinerja kelompok, tetapi disisi lain kebanyakan kelompok dan organisasi berusaha untuk meminimalisasikan konflik Konflik Kerja Terhadap Kinerja Karyawan PT.Pama Indo di Bontang (Yesi) 1399 (Robbins, 2002:91). 


\section{METODE PENELITIAN}

Metode penelitian ini menggunakan metode deskriptif melalui wawancara langsung kepada manajer Toko House Of Celena dan menggunakan metode kualitatif karena sifat dari artikel ini yang menggunakan Teknik pengumpulan data studi pustaka. Studi pustaka yang dimaksud adalah sumber referensi artikel yang diperoleh dari berbagai macam buku dan internet.

\section{HASIL DAN PEMBAHASAN}

Toko Home Of Celena berada di Bangkalan adalah sebuah toko yang menyediakan bahan-bahan fashion dan assesoris, seperti baju, kerudung, tas, dan lain-lain. Toko ini mempunyai kurang lebih 30 karyawan baik wanita ataupun pria, yang mana karyawan tersebut mayoritas adalah penduduk sekitar toko, bukan karena unsur kesengajaan, tetapi memilih memang penduduk disitu masih banyak yang belum bekerja, sehingga melamar bekerja ditoko ini dan diterima.Keharmonisan dan kekompakan pada toko ini sangat erat, karena toko tersebutmenganut asas kekeluargaan, sehingga karyawan disini sudah diibaratkan seperti sebuah tim, yang mana apabila ada yang belum mengerti kan dibantu satu sama lain, keharmonisan ini sesuai dengan keinginan toko dan bias tercapai kinerja yang harmonis, merupakan tujuan dari toko House Of Celena itu sendiri dan konflik di dalam house of celena dapat di selesaikan secara baik dan tidak melibatkan pihak hokum untuk saat ini.

Pada Home Of Celena ini tidak ada sistem pelatihan melainkan sistem bimbingan baik pada karyawan lama maupun karyawan baru yang mana bimbingan tersebut dilakukan oleh para senior yng sudah bekerja di toko tersebut. dengan cara pengenalan produk-produk yang ada ditoko beserta harganya, agar tidak salah memberikan harga dan nantinya tidak terjadi kerugian.

Meskipun memiliki karyawan yang harmonis tidak dapat dihindari terjadinya perselisihan antara karyawan dengan karyawan. Perselisihan yang terjadi bisa dikarenakan perbedaan pandangan atau pendapat. Namun perselisihan yang terjadi di toko celena ini tidak dibiarkan berlarut-larut, karena dari pihak atasannya sendiri jika terjadi sebuah perselisihan akan langsung dilakukan pemanggilan terhada karyawan yang berelisih bahkan diberikan peringatan pada karyawan yang membuat perselisihan tersebut. 
Perselisihan ini biasanya masih bisa dimaklumi oleh atasan karena pekerjaan dalam suatu organisasi tetapi jika sudah berkali-kali masih tetap melakukan kesalahan dan tidak mau berubah terpaksa pemilik toko memberikan surat peringatan SP 1 bahkan sampai dikeluarkan. Namun penyelesaian perselisihan di toko celena diselesaikan secara kekeluargaan dimana atasan memanggil karyawan yang berselisih untuk dipertemukan. Lalu di ambil kesimpulan atau keputusan oleh atasan yang nantinya akan memperbaiki keadaan dan memiliki imbas yang baik bagi pihak atau karyawan lain d di toko tersebut.

Konflik merupakan bagian yang tak terelakkan dari kehidupan organisasi karena tujuan pemangku kepentingan yang berbeda, baik manajer dengan karyawan maupun karyawan dengan karyawan lain yang sering tidak sesuai. Konflik adalah Persaingan yang kurang sehat berdasarkan ambisi dan sikap emosional dalam memperoleh kemenangan.Penanganan situasi konflik dalam karyawan yang tidak tepat dan bijaksana dapat berpengaruh pada suasana kerja karyawan. Hal tersebut tidak berhenti pada situasi itu saja tapi dapat berlanjut menjadi sebuah beban pada karyawan itu sendiri. Kemampuan karyawan dalam menghadapi konflik/tekanan tentu saja tidak sama. Proses tindak lanjut dari penanganan konflik yang melanda karyawan tentu saja harus dilakukan dengan cepat, tepat dan bijaksana terutama bagi karyawan yang memiliki daya tahan terhadap masalah/tekanan yang rendah. Hal tersebut dilakukan untuk menghindari terganggunya sistem kerja, suasana kerja dan yang terutama kinerja dari karyawan itu sendiri. Hasil penelitian yang dilakukan oleh Denny (2010) menemukan konflik mempunyai pengaruh signifikan terhadap kinerja karyawan. Jika tidak ada konflik kerja yang terjadi dalam lingkungan kerja maka kinerja karyawan dapat meningkat dan sebaliknya jika konflik kerja dalam lingkungan kerja sering terjadi maka membuat kinerja karyawan dapat menurun.

Komunikasi untuk menyelesaikan perselisihan antara karyawan dan karyawan mampu berlangsung dengan baik dan jelas, dengan bahasa yang sederhana dan mudah dimengerti.Keharmonisan bisa menjadikan sebuah tokoh maju dan karyawannya sejahtera. Kehamonisan didalam toko celena ini berjalan dengan baik, dimana dengan pengakuan dari pihak manajemen bahwa ketegasan atas sikap manajemen dengan menangggapi permasalahan ataupun kendala-kendala dalam hubungan industrial di tokoh selalu memberikan tanggapan yang baik. 
Perselisihan Hubungan Industrial adalah perbedaan pendapat yang mengakibatkan pertentangan antara pengusaha atau gabungan pengusaha dengan pekerja atau buruh atau serikat buruh karena adanya perselisihan mengenai hak, perselisihan kepentingan, perselisihan hubungan kerja, dan perselisihan antar serikat pekerja atau serikat buruh dalam satu perusahaan. Pihak-pihak yang berselisih dalam hubungan industrial adalah :

1. Pengusaha dengan pekerja atau buruh; atau

2. Pengusaha dengan serikat pekerja atauserikat buruh.

3. Terdapat empat jenis Perselisihan Hubungan Industrial diantaranya :

4. Perselisihan Hak yaitu perselisihan yang akan timbul karena tidak dipenuhinya hak, akibat adanya perbedaan pelaksanaan atau penafsiran terhadap ketentuan peraturan perundang-undangan, perjanjian kerja, peraturan perusahaan atau perjanjian kerja bersama.

5. Perselisihan Kepentingan yaitu perselisihan yang akan timbul dalam hubungan kerja karena tidak adanya kesesuaian pendapat mengenai perbuatan atau perubahan syarat-syarat kerja yang ditetapkan dalam perjanjian kerja atau peraturan perusahaan atau perjanjian kerja bersama.

6. Perselisihan Pemutusan Hubungan Kerja yaitu perselisihan yang biasa timbul karena tidak adanya kesesuaian pendapat mengenai pengakhiran hubungan kerja yang dilakukan oleh salah satu pihak.

7. Perselisihan Antar Serikat Pekerja atau Serikat Buruh Dalam Satu Perusahaan yaitu perselisihan antar Serikat Pekerja atau Serikat Buruh dengan Serikat Pekerja atau Serikat Buruh lain hanya dalam satu perusahaan, karena tidak adanya kesesuaian pemahaman mengenai keanggotaan, pelaksanaan hak dan kewajiban ke serikat pekerjaan. Pembagian perselisihan hubungan industrial menjadi beberapa klasifikasi mensyaratkan bahwa pengetahuan dalam membedakan jenis perselisihan.

Sebab-Sebab Perselisihan antar karyawan

1. Persaingan Terhadap Sumber-sumber Daya yang Langka Setiap divisi dalam took house of celena akan berlomba-lomba untuk mendapatkan bagian dari alokasi sumbersumber daya yang ada. Masing-masing menginginkan alokasi sumberdaya yang banyak agar bisa mempercepat pertumbuhan, kemajuan dan pengembangan dalam divisinya. Karena adanya persaingan ini maka akan memicu timbulnya 
perselisihan . perselisihan ini bisa timbul akibat dari ketersediaan sumber daya yang langka.

2. Ketergantungan Tugas (Interdependence) Dalam toko house of celena sudah pasti adanya ketergantungan antara dua individu atau kelompok untuk mencapai kesuksesan dalam tugas-tugasnya. Apabila diantara dua pihak ini ada perbedaan prioritas, kemungkinan munculnya perselisihan akan semakin besar. Hal ini juga bisa disebabkan oleh keinginan dari kedua belah pihak untuk bisa mencapai otonomi tanpa harus bergantung pada pihak lain. Semakin perbedaan ini dipertahankan maka kemungkinan perselisihan juga akan berlangsung lebih besar bahkan lama. Perselisihan ini biasanya muncul antara dua departemen yang saling bergantung dan sangat terspesialisasi.

3. Kekaburan Batas-batas Bidang Kerja perselisihan mungkin sekali muncul apabila bidang kerja dalam toko huse of celena tidak jelas. Hal ini akan menciptakan suatu kondisi dimana ada seseorang yang mendominasi dalam bagiannya. Apabila ada sebuah keberhasilan maka dia akan merasa dan menunjukkan seolah-olah itu hanya hasil kerjanya sendiri. Akan tetapi apabila ada kesalahan maka dia akan mengalihkannya pada orang lain. Perselisihan juga bisa terjadi apabila ada seseorang yang hanya ingin mengerjakan hal-hal yang disukainya sedangkan yang tidak disukainya akan diserahkan pada orang lain. Pada hakekatnya masingmasing akan merasa yang paling penting dalam kegiatan di toko ini .

4. Kriteria Kinerja yang Tidak Sesuai perselisihan semacam ini disebabkan oleh adanya imbalan atas kemajuan suatu divisi oleh perusahaan.perselisihan bisa muncul apabila kegiatan monitoring dan evaluasi terhadap sub unit-sub unit yang berbeda. Sebagai contoh bagian penjualan menuntut bagian produksi untuk dapat meningkatkan penjualan akan tetapi hal sebaliknya terjadi terhadap bagian produksi. Bagian produksi harus menerima hukuman dengan tidak mendapat bonus karena adanya peningkatan biaya produksi. Peningkatan biaya produksi ini disebabkan oleh bagian produksi harus menambah jam kerja karyawannya untuk dapat memproduksi secara banyak dan cepat. Dapat di tebak apa yang akan timbul, sudah pasti akan ada perselisihan antara bagian produksi dengan penjualan. 
5. Perbedaan-perbedaan Tujuan dan Prioritas dalam perselisihan ini juga bisa disebabkan oleh adanya usaha-usaha masing-masing sub unit untuk mencapai tujuannya masing-masing. Hal ini bisa tumbuh menjadi perselisihan apabila ada ketidak sesuaian antar tujuan masing-masing, bahkan usaha pencapaian tujuan suatu sub unit dapat menghalangi sub unit lain dalam mencapai tujuannya.

\section{Pengertian Pemutusan Hubungan Kerja (PHK)}

Dalam Pemutusan Hubungan Kerja (PHK) dapat terjadi karena berbagai hal, seperti telah berakhirnya waktu tertentuyang telah disepakati/diperjanjikan sebelumnya dapat pula karena adanya perselisihan antara pekerja/buruh, atau karena sebab lain. Menurut Lalu Husni dalam bukunya menyatakan bahwa dalam PHK merupakan suatu peristiwa yang tidak diharapkan terjadinya, terutama dari kalangan buruh atau pekerja karena dengan PHK buruh/pekerjayang bersangkutan akan kehilangan mata pencaharian untuk menghidupi diri dan keluarganya, karena itu semua pihak yang terlibat dalam hubungan industrial baik pengusaha, pekerja/buruh atau pemerintah, dengan segala upaya harus mengusahakan agar jangan terjadi Pemutusan Hubungan Kerja. Dalam Pasal 1 angka 25 Undang-Undang Nomor 13 Tahun 2003 tentang Ketenagakerjaan, menyebutkan bahwa : Pemutusan Hubungan Kerja adalah pengakhiran hubungan kerja karena suatu hal tertentu mengakibatkan berakhirnya hak dan kewajiban antara pekerja/buruh dan pengusaha. Pemutusan Hubungan Kerja bagi pekerja/buruh akan memberikan pengaruh psikologis, ekonomis, finansial, sebabnya :

1. Dengan adanya Pemutusan Hubungan Kerja, bagi pekerja/buruh telah kehilangan mata pencaharian.

2. Untuk mencari pekerjaan yang baru sebagai penggantinya, harus banyak mengeluarkan biaya.

3. Kehilangan biaya hidup untuk diri sendiri dan keluarganya sebelum mendapat pekerjaan yang baru sebagai penggantinya.Pemutusan Hubungan Kerja merupakan peristiwa yang tidak diharapkan terjadinya terutama bagi pekerja/buruh manjadi kehilangan mata pencaharian. Oleh karena itu, untuk membantu mengurangi beban pekerja/buruh yang di PHK, maka peraturan perundang-undangan mengharuskan untuk memberikan hak-hak pekerja berupa uang pesangon, uang jasa, dan uang ganti kerugian. 
Jenis - jenis Pemutusan Hubungan Kerja menurut Lalu Husni, yaitu :

1. PHK oleh pengusaha

2. PHK oleh buruh/pekerja

3. PHK putus demi hukum

4. PHK oleh pengadilan

Diantara jenis-jenis PHK tersebut akan dibahas lebih lanjut mengenai PHK oleh Pengusaha. PHK oleh pengusaha merupakan PHK yang berasal dari kehendak pengusaha, karena adanya pelanggaran atau kesalahan yang dilakukan oleh pekerja/buruh atau karena factor-faktor lain, seperti pengurangan tenaga kerja, perusahaan tutup, perubahan status perusahaan, dan sebagainya. Berdasarkan ketentuan Pasal 153 ayat (1) Undang-Undang Nomor 13 Tahun 2003 tentang ketenagakerjaan, pengusaha dilarang melakukan pemutusan kerja terhadap pekerja/buruh karena alasan :

a. Pekerja/buruh berhalangan masuk kerja karena sakit menurut keterangan dokter selama waktu tidak melampaui dua belas bulan secara berturut-turut

b. Pekerja/buruh berhalangan melakukan pekerjaannya karena memenuhi kewajiban terhadap negara sesuai dengan ketentuan peraturan perundangundangan yang berlaku .

c. Pekerja atau buruh menjalankan ibadah yang diperintahkan kepadanya

d. Pekerja atau buruh perempuan hamil, melahirkan, gugur kandungan atau menyusui bayinya

e. Pekerja atau buruh mempunyai pertalian darah dan/atau ikatan perkawinan dengan pekerja/buruh lainnya didalam suatu perusahaan, kecuali telah diatur dalam perjanjian kerja, peraturan perusahaan, atau perjanjian kerja bersamag

f. Pekerja atau buruh mendirikan, menjadi anggota dan/atau pengurus serikat pekerja atau serikat buruh, pekerja/buruh melakukan kegiatan serikat pekerja atau serikat buruh diluar jam kerja, atau didalam jam kerja atas kesepakatan pengusaha, atau berdasarkan ketentuan yang diatur dalam perjanjian kerja, peraturan perusahan, atau perjanjian kerja bersama

g. Pekerja atau buruh yang mengadakan pengusaha kepada yang berwajib mengenai perbuatan pengusaha yang melakukan tindak pidana kejahatan

h. Karena perbedaan paham, agama, aliran politik, suku, warna kulit, golonga, jenis kelamin, kondisi fisik, atau status perkawinan 
i. Pekerja atau buruh dalam keadaan cacat tetap, ataupun sakit akibat kecelakaan kerja, atau sakit karena hubungan kerja yang menurut keterangan dokter yang jangka waktu penyembuhannya belum dapat dipastikan.

Pemutusan Hubungan Kerja yang sebagaimana dimaksud diatas, dianggap batal demi hukum dan pengusaha wajib mempekerjakan kembali pekerja/buruh yang bersangkutan. Pengusaha dapat melakukan pemberhentian pekerja atau pemecatan apabila terdapat kesalahan dalam berkerja ataupun pemecatan sesuai dengan prosedur yang sudah di atur oleh kebijakan perusahaan. Hal ini diatur dalam ketentuan Pasal 158 ayat (1) Undang-Undang Nomor 13 Tahun 2003 tentang Ketenagakerjaan. Kesalahan berat tersebut harus didukung dengan bukti sebagaimana dalam Pasal 158 ayat (2) UndangUndang Nomor 13 Tahun 2003 tentang Ketenagakerjaan. Sesuai ketentuan Pasal 170 jo Pasal 158 ayat (1) UndangUndang Nomor 13 Tahun 2003 tentang Ketengakerjaan, PHK karena kesalahan berat merupakan salah satu jenis PHK yang tidak memerlukan izin dari Lembaga Penyelesaian Perselisihan Hubungan Industrial, dan dalam hal terjadi PHK tersebut maka pekerja/buruh yang bersangkutan dapat mengajukan gugatan ke Lembaga Penyelesaian Perselisihan Hubungan Industrial.

Pada perkembangan Hukum Ketenagakerjaan, Pasal 158 ayat (1) UndangUndang Nomor 13 Tahun 2003 tentang Ketenagakerjaan, merupakan salah satu Pasal yang menyatakan tidak memiliki kekuatan dalam mengikat secara keseluruhan berdasarkan putusan Mahkamah Konstitusi Nomor 012/PUU-I/2003 tanggal 28 Oktober 2004, karena bertentangan dengan Undang-Undang Dasar 1945 khususnya Pasal 27 ayat (1). Pasal 158 ayat (1) Undang-Undang Nomor 13 Tahun 2003 tantang Ketenagakerjaan memberikan kewenangan kepada pengusaha untuk melakukan PHK dengan alasan pekerja melakukan kesalahan berat tanpa melalui putusan Pengadilan yang memiliki kekuatan Hukum Tetap, sehingga bertentangan dengan asas praduga tak bersalah (presumption of innocence).

Prosedur Pemutusan Hubungan Kerja (PHK) Menurut Abdul Khakim dalam bukunya yang menyatakan bahwa prosedur Pemutusan Hubungan Kerja adalah sebagai berikut :

1. Sebelumnya semua pihak, yaitu pengusaha, pekerja/buruh, serikat pekerja/serikat buruh harus melakukan upaya untuk menghindari Pemutusan Hubungan Kerja (PHK)

2. Bila tidak dapat dihindari, pengusaha dan serikat pekerja/serikat buruh atau pekerja/buruh mengadakan perundingan bersama 
3. Jika perundingan berhasil, dibuat persetujuan bersama

4. Bila tidak berhasil, pengusaha mengajukan permohonan penetapan disertai dasar dan alasan-alasannya kepada lembaga Penyelesaian Perselisihan Hubungan Industrial

5. Selama belum ada penetapan/putusan dari lembaga Penyelesaian Perselisihan Hubungan Industrial, kedua pihak tetap melaksanakan segala kewajiban masingmasing, dimana pekerjatetap menjalankan pekerjaannya dan pengusaha membayar upah

Pada pemutusan hubungan kerja batal demi hukum karyawan/pekerja tidak lagi memiliki kewajiban terhadap perusahaan dan pihak perusahaan tidak lagi memberikan hak-haknya kepada karyawan. Kecuali hak yang berkaitan dengan kompensasi karena sebab-sebab keluar yang diatur oleh peraturan yang berlaku, misalnya pensiun yang harus dibayar setiap bulan (untuk PNS, TNI dan Kepolisian)

Menurut Undang-Undang Nomor 13 Tahun 2003 tentang Ketenagakerjaan, pengertian pemutusan hubungan kerja adalah pengakhiran hubungan kerja karena suatu hal tertentu yang mengakibatkan berakhirnya hak dan kewajiban antara pekerja/buruh dan pengusaha.

Dari kedua definisi di atas dapat disimpulkan bahwa pemutusan hubungan kerja berisi:

1. Berakhirnya hubungan perjanjian kerja antara karyawan dengan pihak perusahaan, artinya karyawan sudah tidak bekerja lagi setelah keluarnya surat pemutusan kerja dan perusahaan tidak mempekerjakan lagi sebagai karyawan. Dan kalau pun tenaganya masih dibutuhkan, maka dapat dikaryakan, namun tetap dipensiunkan lebih dulu. Pada saat dikaryakan karyawan tersebut digaji dengan kontrak tertentu.

2. Dikeluarkannya surat keputusan pemberhentian dengan menyebutkan alasan pemberhentian, baik yang sudah memasuki usia pensiun atau bagi yang mengundurkan diri atau yang dikeluarkan.

3. Perusahaan membayar hak-hak karyawan sesuai dengan peraturan perundangundangan yang berlaku, seperti misalnya uang pensiun (baik sekaligus atau bulanan), uang jasa, uang penghargaan atau uang lainnya.

4. Karyawan diwajibkan membayar kewajiban atas perbuatannya jika ada, khusus untuk karyawan yang diberhentikan dengan alasan tertentu. terutama yang 
merugikan perusahaan, misalnya mengganti akibat perbuatannya. Khusus bagi mereka yang pendidikanya dibiayai perusahaan dan masih dalam ikatan dinas, maka diwajibkan mengganti biaya pendidikan sesuai dengan perjanjian yang sudah dibuat sebelumnya.

Perlu diingat bahwa pemutusan hubungan kerja antara karyawan dengan pihak perusahaan harus dibuktikan dengan surat pemberhentian kerja, dengan disertai pembayaran hak dan kewajiban masing-masing pihak. Adapun bentuk jenis surat pemberhentian terdiri dari:

1. Dengan hormat

Artinya pemutusan hubungan kerja dilakukan dengan baik-baik, karyawan diperlakukan dengan baik, dengan memberikan sejumlah penghargaan atas jasajasanya, termasuk sejumlah kompensasi atas jasanya selama ini terhadap perusahaan. Jenis pemberhentian seperti ini misalnya sudah memasuki usia pensiun. Diberhentikan perusahaan karena memang terjadi rasionalisasi atau pengurangan tenaga kerja akibat pengurangan produksi atau lainnya. Faktor lainnya dapat terjadi jika mengundurkan diri secara baik-baik, artinya tidak terdapat masalah dengan pihak perusahaan. Dengan tidak hormat Artinya pemutusan hubungan kerja dilakukan dengan tidak baik, akibat perbuatan karyawan yang telah merugikan perusahaan.

2. Dengan tidak hormat

Artinya pemutusan hubungan kerja dilakukan dengan tidak baik, akibat perbuatan karyawan telah merugikan perusahaan, misalnya melakukan tindakan pencurian atau kecurangan yang merugikan baik materil maupun merusak citra perusahaan. Perusahaan tidak akan memberikan sejumlah kompensasi atau penghargaan apa pun jika pemutusan hubungan kerja dilakukan dengan tidak hormat. Bahkan bukan tidak mungkin karyawan yang diputuskan dengan tidak hormat akan menghadapi tuntutan di pengadilan dan penggantian sejumlah kerugian yang telah dilakukannya.

Kemudian alasan seseorang diberhentikan bisa bermacam-macam tergantung dari kasusnya masing-masing. Dalam praktiknya terdapat beberapa jenis pemutusan hubungan kerja yang sering dilakukan. Hal ini dilakukan dengan berbagai sebab, sehingga perlu 
dilakukan pemberhentian. Berikut ini jenis pemutusan hubungan kerja ditinjau dari jumlah yang diberhentikan yaitu:

1. Pemutusan hubungan kerja individu

Artinya yang diberhentikan adalah pribadi atau orang per orang dengan batas waktu tertentu. Dalam kasus ini sering terjadi misalnya karyawan memasuki usia pensiun, sehingga jumlahnya tidak banyak karena ada batas waktu untuk pensiun. Atau perbuatan curang yang dilakukan oleh individu, sehingga pemberhentian hanya kepada si pelaku yang berbuat kecurangan atau kerugian perusahaan.

2. Pemutusan hubungan kerja kelompok

Merupakan Pemutusan hubungan kerja yang dilakukan kepada sekelompok karyawan (lebih dari seorang). Pemutusan hubungan kerja kelompok terjadi kepada sekelompok karyawan yang melakukan pencurian atau kecurangan yang membuat perusahaan menderita kerugian. Atau akibat dari sekelompok karyawan mengundurkan diri dengan alasan tertentu, misalnya menuntut kenaikan upah atau keselamatan kerja.

3. Pemutusan hubungan kerja massal

Pemutusan hubungan kerja masa adalah pemutusan yang dilakukan terhadap sejumlah karyawan dengan berbagai sebab. Misalnya karena ketidakmampuan perusahaan sehingga terjadi pengurangan karyawan, seperti penutupan unit atau cabang atau pabrik tertentu, sehingga terjadi pengurangan karyawan(rasionalisasi). Penutupan ini tentu saja membawa konsekuensi pemberhentian seluruh atau sebagian dari mereka yang terkena kebijakan pemutusan hubungan kerja. Pemutusan hubungan kerja ini untuk mengurangi beban biaya tenaga kerja yang dikeluarkan, mengingat dengan penutupan sebagian usaha akan banyak tenaga yang menganggur.

\section{KESIMPULAN DAN SARAN}

Dapat di simpulkan bahwa di Toko House Of celena mempunyai sistem kekeluargaan dan cara penyelesaian yang cukup sampai mediasi antara karyawan dan manajer dapat terselesaikan dengan baik. Saran kepada toko celena bahwa tetaplah menjaga suasana pekerjaan yang harmonis, dan lebih mempererat harmonisasi dan tidak menimbulkan kesenjangan antar karyawan karena jika lingkungan pekerjaan telah nyaman 
dan berdampak pada eksistensi toko tersebutKomunikasi antara atasan dan bawahan maupun sebaliknya di toko Indah Barokah berlangsung dengan baik dan jelas. Pesan di sampaikan secara lisan dalam proses wawancara yang telah di lakukan. Informasi di jelaskan secara terperinci, dengan bahsa yang sederhana dan dimengerti.

1. Disarankan bagi pihak toko untuk tetap mempertahankan hubungan industrial yang sudah baik dan komunikasi yang baik untuk menyelesaikan masalah antara atasan dan bawahan.

2. Disarankan bagi pihak toko untuk tetap mempertahankan ketegasan sikap dan keputusan demi kelancaran toko dan kesejahteraan karyawan.

\section{DAFTAR PUSTAKA :}

Anatan, Lina., \& Ellitan, Lena. 2009. Manajemen Sumber Daya manusia dalam Bisnis Modern. Bandung : Alfabeta.

Anatan, Lina., 2003. Konflik Antar Kelompok Dalam Organisasi: Tinjauan Teoritis dan Pengaruhnya Terhadap Kinerja Organisasi.

Haryanto dkk. 2009. Sistem Sosial Budaya Indonesia. Jakarta: Universitas Indonesia.

Handoko, T Hani. 2005. Manajemen Personalia \& Sumber Daya Manusia Cetakan Kesebelas. Yogyakarta: BPFE UGM.

Kasmir. 2016. Manajemen Sumber Daya Manusia Teori dan Praktek. Jakarta: PT Raja Grafindo Persada.

Khakim, Abdul. 2010. Aspek Hukum Penyelesaian Hubungan Industrial. Bandung: PT Citra Aditya Bakti.

Lalu Husni.2006. Pengantar hukum Ketenagakerjaan Indonesia, ed. Revisi, 6,Jakarta: PT. Raja Grafindo Persada.

Robbins, Stephen P. dan Timothy A. Judge. 2008. Perilaku Organisasi Edisi ke 12, Jakarta:Salemba Empat

Syahrizal Abbas. 2009. Mediasi Dalam Perspektif Hukum Syariah, Hukum Adat, dan Hukum Nasional. Penerbit Kencana Prenada Media Group : Jakarta.

Takdir Rahmadi, 2010, Mediasi: Penyelesaian sengketa melalui pendekatan mufakat, Jakarta: PT Raja Grafindo Persada.

Undang-Undang Nomor 13 Tahun 2003 tentang Ketenagakerjaan.

Undang-Undang Nomor 2 Tahun 2004 tentang PP

Zaeni Asyhadie. 2007. Hukum Kerja, Jakarta: PT Raja Grafindo Persada. 